\title{
CÂNCER GÁSTRICO E HÉRNIA INGUINAL NO MESMO DOENTE
}

M.T., 7 I anos, brasileiro, casado, natural e procedente de São Paulo, SP

Queixa duração - Dor na "boca do estômago" há 2 anos e "tumor na barriga baixa" há 15 anos.

Históriapregressa da moléstiaatual-Refere o doente que há 15 anos apresenta "bola" na barriga do lado direito baixo, que surge aos esforços inclusive da tosse e desaparece com o repouso ou manobras manuais.

Há dois anos passou a ter intolerância à carne e diminuição progressiva do apetite, acompanhados de fraqueza e emagrecimento de $10 \mathrm{Kg}$ neste período.

Antecedentes pessoais - Doenças próprias da infância.

Antecedenteshereditáriose ISDA- Nada significativo

Exame físico geral - Regular para mau o estado geral, atrofia da musculatura intercostal, dos pronadores e desaparecimento da bola de "Bichat".

Exame protológico-normal.
Exame físico local - Hérnia inguinal escrotal a D. redutível.

Examefííico especial-Cabeça e pescoço sem particularidades

Aparelho respiratório - roncos disseminados, alguns estertores sub crepitantes nas bases

Aparelho circulatório - n.d.n.

Abdome - ausência da ascite. Não se palpam tumores.

RHA-normais.

Sistema nervoso e membros - nada a referir.

\section{Exames:}

hemograma

Proteínas totais e frações

Uréia

Glicemia

Urina I

Coagulograma

Endoscopia - Lesão vegetante Borman II na região antral, preservando o piloro que é transponível ao aparelho - Duodeno normal.
U.S. Abdome - Espessamento da parede gástrica

Ausência de linfonodomegalia

Diagnóstico - Neoplasia do antro gástrico

Hérnia ínguino-escrotal à direita

Conduta - Herniorrafiainguinal, gastrectomia subtotal com dissecção a D 2

Classificação - TNM, TI N。 M.

\section{Dıscussão}

O interessante deste caso é a realização da herniorrafia inguinal precedendo a gastrectomia no mesmo ato cirúrgico. Nossa experiência, nestes casos, é de que a hérnia não operada pode complicar no pós-operatório da gastrectomia com estrangulamento ou encarceramento, pelo aumento da pressão intracavitária, levando a nova agressão anestésico-cirúrgica. Portanto, é preferível sempre realizá-la eletivamente no mesmo ato cirúrgico do que em caráter de urgência, pois neste caso poderá complicar o pósoperatório da cirurgia abdominal.

\section{Departamento de Cirurgia da Faculdade de Ciências Médicas da Santa Casa de São Paulo.}

